\title{
Enhancing Teaching Skills Towards Lesson Study
}

\author{
Ahmad Supriyanto ${ }^{a}$, Ferril Ilham Muzakki ${ }^{a}$ \\ ${ }^{a}$ Universitas Negeri Malang, Malang, Indonesia \\ Corresponding e-mail: aspriess@gmail.com
}

\begin{abstract}
This lesson study is purposed to improve the quality in teaching and learning process, esspecially in university levels. The students are taken from elementary teachers training program at their first year in their university degrees. The method is done by planning, action and re-planning. The results are the discussion methods are changed by activating every students in classroom during the school time. The second results are changing the discussion pattern through activating the students in question and answer section. Thus, it is suggested for future researcher to improve this study by relate with models in teaching.
\end{abstract}

Keywords: Lesson study, discussion methods, models of teaching

\section{INTRODUCTION}

It has been widely believed that teachers have to update their knowledge to transform ideas and also their education system. Nowadays, teachers have to be obligated in transforming ideas and making selfevaluation to be a better teacher in society. Thus, this plan will make easier to be developed by showing off the real problem in society according to Florian [1]. This plan is should be included in redesign the structure of an events in classroom and also in society.

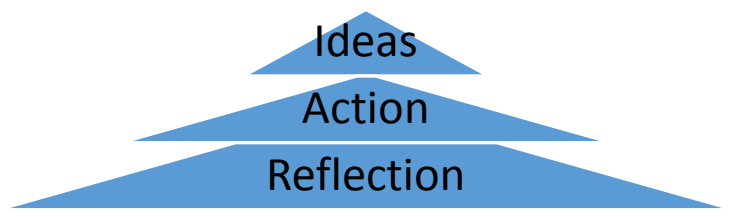

Figure 01: adopted from Amador \& Weiland (2015:110).

For recent years, the teaching methods had already transfrom, from teachers as the instructor into teachers as facilitators. Meanwhile, accroding to Bamberg, Rees \& Seebauer (2015:156) the society had already change into collectivism. On the other side, it could be conclude that this new paradigm give the teacher view that they have to have capabilities to make reflection for their self. This idea give the point of view that lesson study is an important thing to be done.

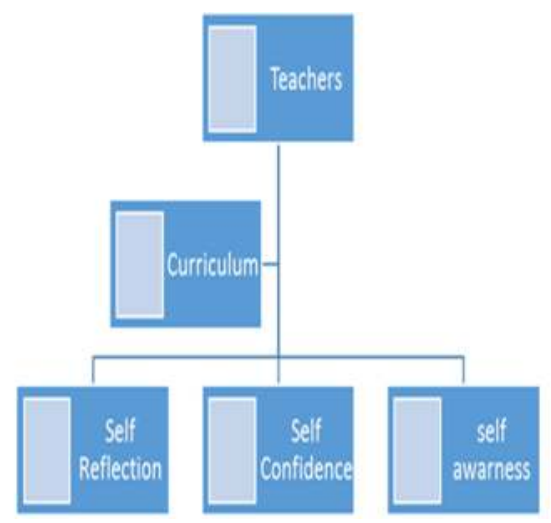

Figure 02. Martin\& Clerc-Georgy. (2015:262)

It could be concluded that lesson study is important for teachers and also university lecturers to improve their skills in teaching. It is more important to make lesson study since as a lecturer $\mathrm{i}$ need to improve my teaching skills for university students. 
Figure 03. Adopted from Alemida and Monteiro (2017)

Thus, the interpretation of the user experience in lesson study are could be done by seeing relation among teachers, students and stakeholders. It means, there have to synergy among those elements to accomplish the goal in lesson study.

\section{METHODS}

The lesson study has three steps; those are planning, teaching and re-planning. For those sections, it has a meeting by the teachers and observers to enhance quality of teaching and learning process. The methods are explaining bellow.

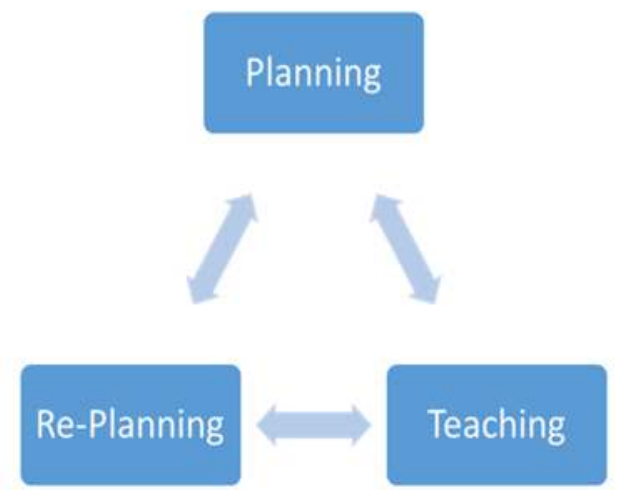

Figure 04. Adopted from Hadfield \& Jopling [2]

The cycle of planning and after the planning season, it needs a teaching section and the last is replanning to evaluate the results also prepare for the next planning. Thus, it could be concluded that the planning will develop ideal way to suggest the situation.

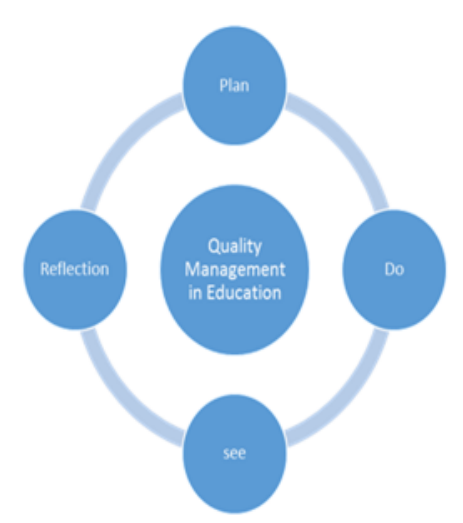

Figure 05. Adopted from Asgher, et all [3]

The other cycle from Asgher, et all [3] are showing that lesson study have to be done by four steps, those are Plan (develop the lesson plan together, do (doing the lesson study), see (other members are see the results), and reflection, (the members have done a reflection of a teaching and learning process). Thus, the cycle does it continuously to improve the quality of teaching and learning process. It means, the lesson study program also able to be done for teachers training preparation program, in bachelor degree.

\section{RESULTS}

The result of this study has found that there is an improvement in discussion method during and after the lesson study. Thus, the result will explain bellow, in two section. The first is the improvement in classroom discussion method and the second is the improvement the design of classroom discussion method.

\subsection{Improvement of Classroom Discussion Method}

The discussion method is improved. It means that the students have to be taught by discussion. The previous section there presenter is active while the listener has raised question and wait the answer from the audience. After lesson study the presenter and participants has been activating their ideas to discuss the answer. This result clarifies the research finding from Florian [1]. 
Figure 06. Adopted from Florian [1]

In this section, the implementation of discussion has been activating the students performance, it could make students are easier to send and receive the ideas.

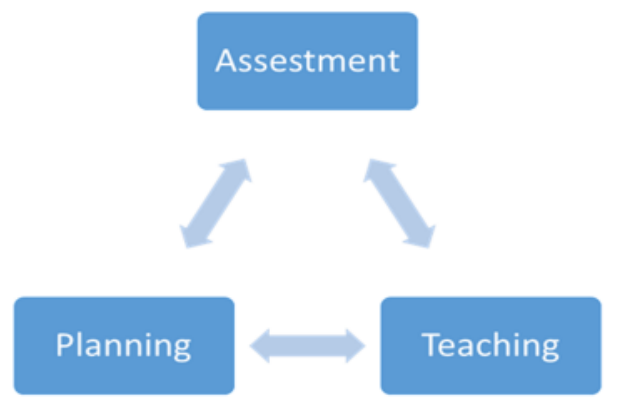

Figure 07. Adopted from Brudler, et all [4]

Brudler, et all states that the assestment, teaching and planning process are connected each others. It means that the teacher's model have to construct the ideas based ont the assestment process.

\subsection{Improving the Desing of Classroom Discussion}

The lesson study is designed to improve the quality of teaching and learning process. Further, this idea give the perfection of teaching and learning process in classroom according to Dudley [5]. In which, this process make the lesson study improve the teaching and learning process in classroom.

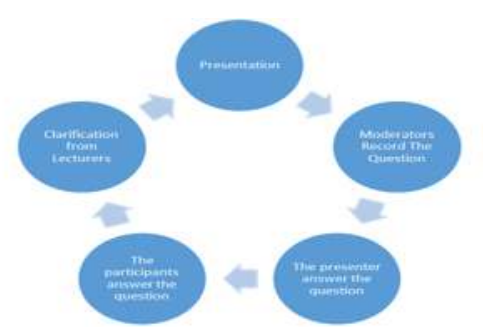

Figure 08. Adopted from Brudler, et all [4]

Thus, the cylces are activating the participation of the students. In which the result, the students make the result is improving. It could be seen by the class, before the lesson study, looks have not activated yet and after the lesson study, the classroom activities become active and the discussion walk throughout the learning time.

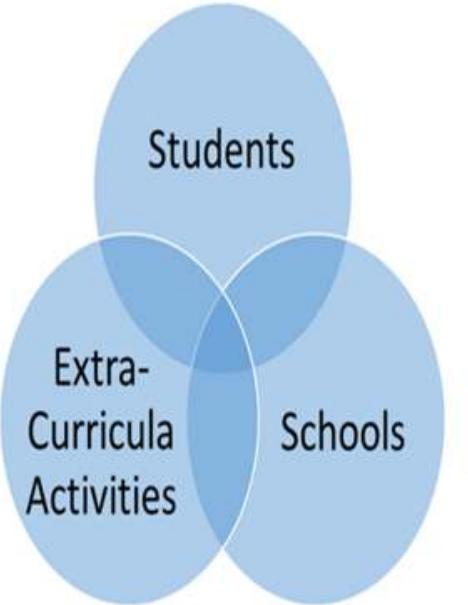

Figure 09. Adopted from De Vries, et aII (20I2)

Thus, the lesson study have to connect with the shareholders in schools. Thus, the shareholders have to be related on the schools activities.

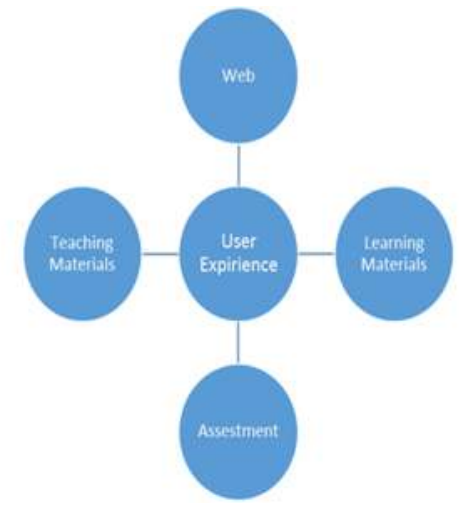

Figure 10. Adopted from Hussein, et all [6]

The user experience by the students are relates on the website, learning materials, assessment and teaching materials.

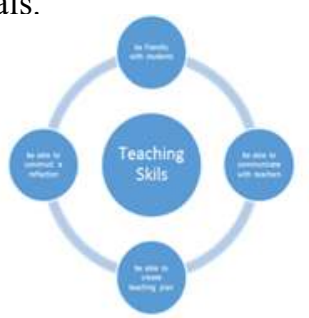

Figure 11. Adopted from Owens [7]

Thus, the teaching skills are constructed with the abilty to empathy with the studnets. Thus, it could be reflected by be friendly with the students, able to 
communicate with teachers, able to create the teaching plan, be able to construct a reflection.

\section{Online \\ Materials}

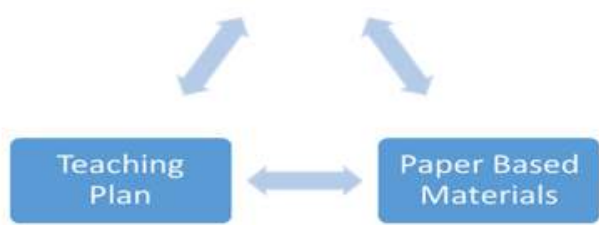

Figure 12. Adopted from Moffett, et all [8]

The relation among online materials, are constructed by paper based and the teaching plan. Thus, the online materials are connceted with the teaching lan and the paper based plan.

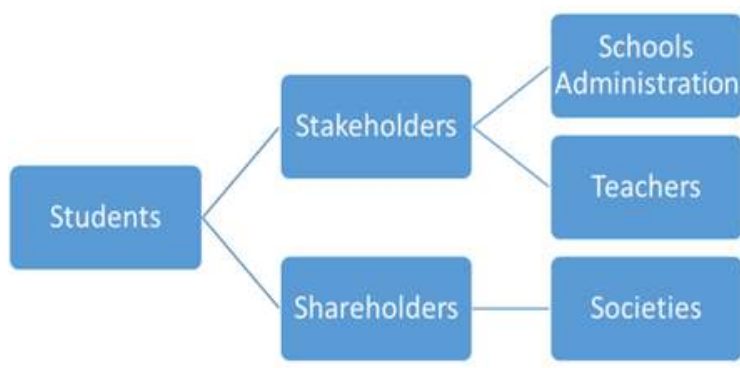

Figure 13. Adopted from Cabal and Mikulecky [9]

Thus, the students have to deal with the stakeholders, schools administration and teacher. The other concept, students have to deal with the shareholders, it relates on societies.

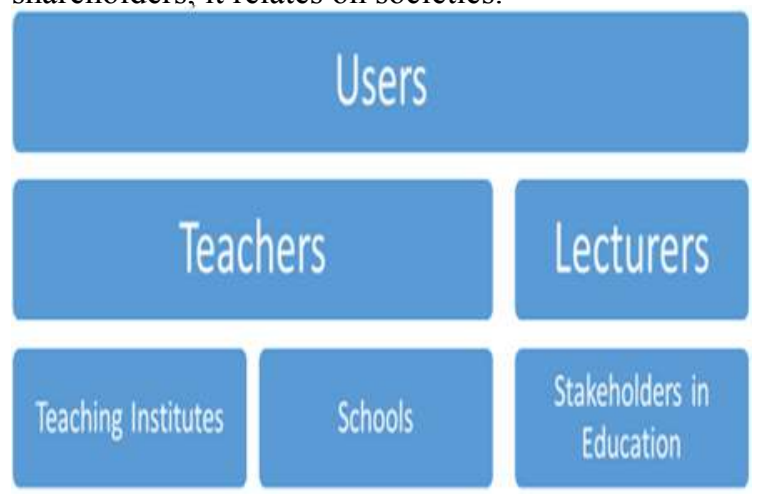

Figure 14. Adopted from Getto, et all [10]

The lesson study, are able to construct the synergy among the teachers and the teaching institute. It means that the users are able to construc the ideas from lesson study.

\section{CONCLUSION}

Both, by the lesson study on this section, there are two results. First result is the improvement the discussion method. The second method is the improvement of the design of discussion. The first result, the discussion method has changed by let the students become leader of discussion not the lecturer, the lecturer give the explanation after the discussion section. The second result, after the discussion the students have to answer the question that is written by themselves using Jigsaw and it is own variation. Based on this result, it is suggested for next researcher to explore more on jigsaw and it is own variation to improve the quality of discussion in mash-up with active learning.

\section{REFERENCES}

[1] Florian, L. (2012). Preparing teachers to work in inclusive classrooms key lessons for the professional development of teacher educators from Scotland's inclusive practice project. Journal of Teacher Education, 63(4), 275-285.

[2] Hadfield, M., \& Jopling, M. (2016). Problematizing lesson study and its impacts: Studying a highly contextualised approach to professional learning.Teaching and Teacher Education, 60, 203-214.

[3] Asgher, U., Leba, M., Ionică, A., Moraru, R. I., \& Ahmad, R. (2015). Human factors in the context of excellence models: European Foundation for Quality Management (EFQM) excellence software model and cross-cultural analysis.Procedia Manufacturing, 3, 3948-3954.

[4] Brudler, S., Arnbjerg-Nielsen, K., Hauschild, M. Z., \& Rygaard, M. (2016). Life cycle assessment of stormwater management in the context of climate change adaptation. Water Research, 106, 394-404.

[5] Dudley, P. (2013). Teacher learning in Lesson Study: What interaction-level discourse analysis revealed about how teachers utilised imagination, tacit knowledge of teaching and fresh evidence of pupils learning, to develop practice knowledge and so enhance their pupils' learning. Teaching and teacher education, 34, 107-121.

[6] Hussein, I., Mahmud, M., \& Tap, A. O. M. (2014, June). HCI knowledge for UX practices in the web development process. In International Conference of Design, User 
Experience, and Usability (pp. 116-126). Springer International Publishing.

[7] Coles, E. K., Owens, J. S., Serrano, V. J., Slavec, J., \& Evans, S. W. (2015). From consultation to student outcomes: The role of teacher knowledge, skills, and beliefs in increasing integrity in classroom management strategies. School Mental Health, 7(1), 34-48.

[8] Moffett, J. (2014). Bridging UX and Web Development: Better Results Through Team Integration. Morgan Kaufmann.

[9] Cabal, J., \& Mikulecký, P. (2016, October). How Czech Universities Cover Web Development Teaching in Their Curricula. In European Conference on e-Learning (p. 729). Academic Conferences International Limited.

[10] Getto, G., Thompson, R. J., \& Saggi, K. (2016, October). Spurring UX innovation in academia through lean research and teaching. In Professional Communication Conference (IPCC), 2016 IEEE International (pp. 1-9). IEEE.

[11] Almeida, F., \& Monteiro, J. A. (2017). Approaches and Principles for UX Web Experiences: A Case Study Approach. International Journal of Information Technology and Web Engineering (IJITWE), 12(2), 49-65.

[12] Aloe, A. M., Amo, L. C., \& Shanahan, M. E. (2014). Classroom management self-efficacy and burnout: A multivariate metaanalysis. Educational psychology review, 26(1), 101-126.

[13] Amador, J., \& Weiland, I. (2015). What preservice teachers and knowledgeable others professionally notice during lesson study. The Teacher Educator, 50(2), 109-126.

[14] Martin, D., \& Clerc-Georgy, A. (2015). Use of theoretical concepts in lesson study: an example from teacher training. International Journal for Lesson and Learning Studies, 4(3), 261-273. 